\title{
Mainstreaming Mineral Wealth in Growth and Poverty Reduction Strategies
}

By Antonio M.A. Pedro

Sustainable Developme $\mathrm{nt}$ 


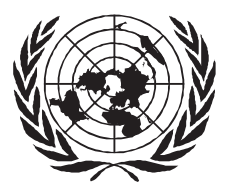

Economic Commission for Africa

\title{
Mainstreaming Mineral Wealth in Growth and Poverty Reduction Strategies
}

\author{
By Antonio M.A. Pedro ${ }^{1}$ \\ P.O. Box 3001 \\ Addis Ababa, Ethiopia \\ E-mail: apedro@uneca.org
}

${ }^{1}$ Antonio Pedro is a Senior Economic Affairs Officer and leader of the Natural Resources Development team of the Sustainable Development Division (SDD) of the United Nations Economic Commission for Africa (ECA). 


\section{Table of Contents}

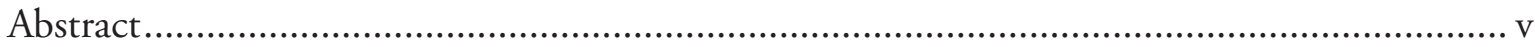

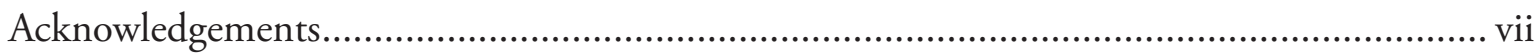

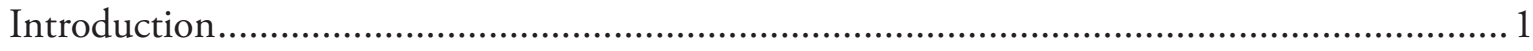

Views on Mining: The Natural Resources Curse Argument .................................................

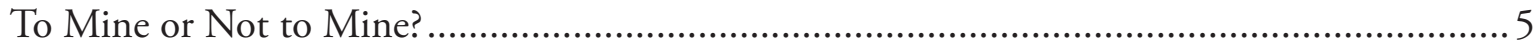

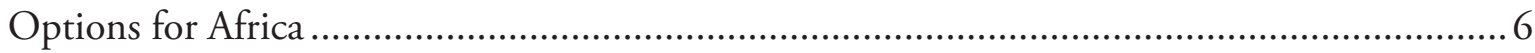

Improving Public Participation in Mineral Resources Development............................ 10

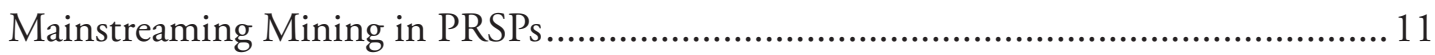

Improving Management of Mineral Revenue: The Case of Stabilization Funds and Non-renewable Resource Funds (NRFs) .................................................. 12

Fostering Minerals Cluster Development ................................................................ 13

Improving Sustainability in Artisanal and Small-scale Mining (ASM) ......................... 15

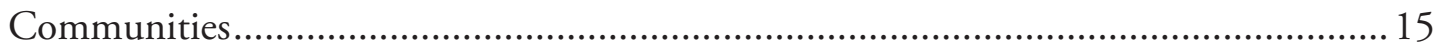

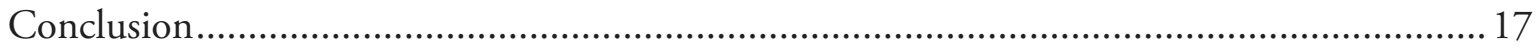

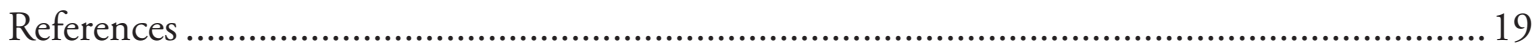

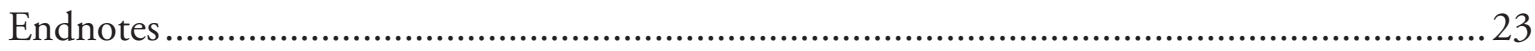




\section{Abstract}

Many studies claim that mineral resources impact negatively on economic growth particularly in developing countries. This paper briefly reviews this argument (the natural resources curse hypothesis) and subjects it to examination. The paper argues that poor performance is not an inherent characteristic of minerals-driven economies. It considers mineral endowments a capital that can spur growth and reduce poverty in developing countries if deployed under appropriate conditions. The paper identifies the benefit streams of mining and the challenges for their equitable creation, investment, distribution and management. It articulates the conditions, success factors and strategies to maximizing the contribution of the minerals sector to growth and development in Africa. They hinge on creating a conducive and competitive policy, legal and regulatory environment and framework for business development; improving governance and management systems anchored on strong and capable institutions; opening up opportunities, sharpening investment decisions; promoting linkages between the minerals sector and other sectors of the economy; empowering communities, establishing coalitions of change, and facilitating knowledge and competencies creation.

Keywords: Minerals, mining, resource curse, Africa, developing countries, poverty reduction, growth, wealth, benefits, linkages and governance. 


\section{Acknowledgements}

This paper has benefited from substantive and editorial comments and inputs from Yinka Adeyemi, Maria Thundu, Augustin Fosu, Chantal Dupasquier, Wilfred Lombe, Oliver Maponga, Albert Yama, Awa Busia, Isatou Gaye, Bjorg Sandkjaer, and Yousif Hassan, all from ECA. The first draft of the paper was submitted for validation to an ECA Seminar Series held on 30 April 2004, facilitated by Kasirim Nwuke and chaired by Mr Josue Dione, Director of the Sustainable Development Division of ECA. About 30 ECA staff members attended the seminar. Their valuable comments have been taken into consideration in finalizing the paper. Contributions external to ECA were received from Olle Ostenson, Magnus Ericsson, Pentti Noras, Jesse Czelusta, Gavin Hilson and Brigitte Bocoum. To all, the author extends his sincere gratitude. 
"The revenue of the State is the State" in Edmund Burke (1993).

"A windfall coming from a terms-of-trade improvement or a discovery of natural resources can lead to a feeding frenzy in which competing factions fight for natural resource rents, and end up inefficiently exhausting the public good" in Lane and Tornell (1995)

\section{Introduction}

Mining has been under scrutiny for quite some time. Many stakeholders have felt that the costs of mining outweigh its benefits, particularly in developing countries. Some constituencies have, for example, asked the World Bank Group to stop its assistance to the sector. In the quest for a more societal oriented and environment-conscious mining sector and to respond to the critics of mining and the distrust generated from a legacy of poor performance and unmet expectations in terms of its contribution to equitable growth and poverty reduction, unprecedented consultative processes have been initiated to charter a new social contract for mining.

In 2000, the corporate world initiated a two-year independent process of research and consultation, the Mining, Minerals and Sustainable Development Project (MMSD), to examine the role of the minerals sector in contributing to sustainable development. The project resulted in a ground-breaking report (MMSD, 2002), with a set of recommendations and an agenda for change addressed to industry, governments, civil society and other stakeholders. On the other hand, in 2001 the World Bank launched an extensive review process, the Extractive Industries Review (EIR), of its mandate and role in mining aimed at producing a set of recommendations that would guide future involvement of the World Bank Group in the oil, gas and mining sectors. The discussion was within the context of the World Bank Group's overall mission of poverty reduction and the promotion of sustainable development. The EIR Final Report and recommendations were published in December 2003.

The report noted that investments in the extractive industries could contribute to sustainable development if the benefits from mining are well-used. However, while endorsing a continuing role for the Bank in supporting extractive industries, the report observed that the Bank must further enhance its efforts in several areas, particularly on identifying and tracking poverty reduction associated with the projects it finances. It calls for reforms and urges the Bank to give more priority to issues such as greater disclosure and transparency of revenue management, improvement of governance in host countries, broader inclusion and participation of local stakeholders, and promotion of renewable energy. Furthermore, it asks the Bank to require higher standards for delivering social and environmental protections and benefits and to strengthen environmental and social requirements for its investment in extractive industries (EIR, 2003).

Other notable initiatives to improve governance in the extractive industries include the "Publish What You Pay Campaign" launched by a group of NGOs and the Extractive Industries Transparency Initiative (EITI) sponsored by the British Government. Several guidelines, protocols, codes of practice, organizational policies and management systems and voluntary undertakings and statements of principle have been instituted 
to help improve conduct and practices with a view to achieving sustainable development in the minerals sector. There is a better understanding now of what it means and what it is required to promote sustainability in mining. This bodes well for the future of mining.

This paper revisits some of the issues at the fore of the development debate on mining. The paper is part of an initiative by the Sustainable Development Division (SDD) to articulate policy options for African countries in some of its core areas of activity. These include agriculture and food security; land resources management; natural resources development; science and technology innovation; and sustainable development monitoring. The paper aims to raise awareness among policy-makers and practitioners on the development issues and public policy challenges of managing mineral wealth to promote growth and reduce poverty in Africa and to offer insight, policy options and strategies to address those challenges. The paper draws from ECA's own analytical work, the joint ECA/United Nations Conference on Trade and Development (UNCTAD) Training Materials on "The Role and Management of Mineral Wealth in Socio-economic Development"(ECA, 2003) and best practices from Africa and other regions. It is informed by the results of processes like MMSD and EIR.

\section{Views on Mining: The Natural Resources Curse Argument}

There is an extensive body of theoretical and empirical literature on the role of mineral resources in economic development. The schools of thought are divided between those who argue that mineral resources are a curse and that, in general, growth in mineral-rich and dependent economies has been worse than in less endowed countries and scholars who consider mineral resources an endowment that has the potential to spur growth and development in developing countries.

Those who are not persuaded about the role of mining as a growth engine reason that most mining in developing countries is a capital-intensive enclave industry, foreign-owned, operated largely by expatriates, and uses inputs (especially equipment) purchased abroad. In addition, they state that output, income and employment multipliers in mining, as well as its learning-by-doing potential ${ }^{2}$ are lower than in other sectors, particularly manufacturing. This view is reflected and typified almost in unison in studies by Auty (1991, 1998, 1999 and 2001), Sachs and Warner (1995), Mikesell (1997), and Ross (1999, 2001 and 2002), who argue that the richer the natural resource endowment, the greater the likelihood of decelerating economic growth. Accordingly, the boom and bust nature of mining is said to engender poor development performance and substandard welfare social indicators. They further observe that the record of oil and mineral rich states in alleviating poverty is worse than states with similar levels of income, but little or no oil and mineral wealth.

These scholars suggest that the pattern of underperformance in mineral economies could be linked to growth inhibition caused by several factors that work in tandem. They include the Dutch Disease ${ }^{3}$; endowment-related alliances with powerful vested interests in securing control of mineral rents; decline and instability in the terms of trade for mineral commodities; lack of local capacity to predict the magnitude 
of government revenues and foreign exchange earnings and hence to plan expenditure and investment; allowance for profligate social and infrastructure spending, which usually continues even when reserves or revenues decline; and the enclave nature of mining.

Some researchers (e.g Moore, 2000) have suggested that political under-development ${ }^{4}$ may be at the root cause of the underperformance of mineral economies while others contend that resource booms produce a false sense of security, overconfidence and illusions of plenty among policy-makers and tend to weaken state institutions. For example, Snider (1996) asserts that mineral production creates rentier states, and weakens them, because they have lesser political extractive capacity to tax their constituencies. Revenues from mining production remove the need for these governments to penetrate their societies to levy and extract more taxes from the population. Consequently, in times of crisis, such countries are rendered vulnerable because they are far less capable of mobilizing the human and material resources of their societies to meet external threats. It is further said, that access to easy money (mineral wealth) lowers financial discipline, leads to reckless budgetary practices and weakens traditional work ethics, since the majority would be involved in the distribution or utilization of the mineral wealth rather than in creating other forms of wealth.

In that vein, Power (2002) notes, "when mineral development occurs in a context of underdeveloped social, political, and economic institutions, the non-renewable resource wealth tends to be squandered, the level of social conflict increases and nearly irreparable damage is inflicted on the environment". $\mathrm{He}$ further emphasizes that these developments can leave a developing nation permanently poor. Referring to the role played by mineral resources in the development of Canada or Australia, Power argues that the minerals-led industrialization in those countries was not driven by the mineral resources endowment per se, but by an "overall transformation in business and financial organization, education, research and knowledge development, human capital accumulation and infrastructure expansion". He affirms that well-developed and stable political institutions that respected the rule of law, markets and private enterprise played an equally important role in fostering this industrialization.

Other skeptics have pointed to South Korea and Japan as resource-poor nations that have succeeded, and quote sub-Saharan Africa as a classic example of the detrimental effects that natural resource abundance can have on economic growth. They contend that, in sub-Saharan Africa, abundance of mineral resources can accelerate the route to poverty because, in many cases, human capital creation and accumulation is neglected, governments are not responsive to the needs of the poor, social infrastructure is weak, economic policy is dysfunctional, rent-seeking prevails, corruption reigns, public income is squandered by the elite in power and those close to it, and wars of attrition and conflicts are common. Above all, they state that growth levels are low, the type of growth and patterns of spending are not pro-poor and inequality is very high. This makes growth enhancing policies difficult to implement and poverty reduction difficult to achieve. Furthermore, they observe that poor people in mineral rich countries are more vulnerable and exposed to risks because those countries are more exposed to economic shocks due to their lack of diversification and the cyclical nature of commodity prices.

They further argue that mining is an inflexible sector because it requires sector-specific infrastructure (power grids, roads, ports) and investments in specialized physical and human capital that are unusable in other production activities which lends a degree of rigidity to the economy. Shaffer (1986) notes that 
"the loss of flexibility to restructure the mineral economy in a volatile global economy leads to an inability to respond naturally to mineral price shocks. This in turn causes the state to become involved in lifesaving exercises due to the mineral sector's incapacity to manage market risks. Demands on the state for relief are large during market downturns, yet these demands coincide precisely with periods where state revenues are at their lowest. The result is a sub-optimally developing economy, so much that minerals can impoverish rather than enrich”.

On the opposite camp, a group of scholars (Ahammad and Clements, 1999; Clements and Johnson, 2003; Davis, 1998; Davis and Tilton, 2002; Goodland, 2002) point out that the reported negative outcomes of mineral economies are case-specific and that economic performance is mixed, heterogeneous and should not be generalized. Some contend that, for example, among African mineral economies there are fast growing economies (e.g. Botswana) and those with negative growth (e.g. Zambia). Others further argue that if mining would be excluded, growth rates of many African countries would be even lower and that mineral rich countries should make immediate use of their wealth in case it becomes uneconomic at a later date. They note that, in Africa, other sectors, such as agriculture and particularly manufacturing, are not knowledge-driven nor are they globally competitive or performing better than mining. Their intersectoral multiplier effects and linkages are negligible. On infrastructure, they note that the social and physical infrastructure created for mining can be restructured to other applications.

To refute the lower growth theory, they state that there is no consistent statistical evidence that show that mineral dependence leads to either faster or slower economic growth and that without evidence of a general law upon which to build, the past successes and failures of the mineral economies remain idiosyncratic, refuting any broad generalization on development patterns. As Davis (1998) notes, "When the entire set of mineral economies is examined, the heterogeneity and inter-temporal variability of their performances prevents any useful typification". For them, the problems associated with mineral dependence are political rather than economic and they can be linked to the capacity of governments and society to respond to large windfall revenues from mineral production. In most cases, these revenues are squandered rather than productively invested.

Stijns (2001) observes that it is the primary export intensity rather than natural resources per se that has a significant negative influence on growth rates. He further indicates that natural resources affect economic growth through both positive and negative channels and that what matters most in terms of economic development is what countries do with their natural resources. He notes that those who object to the exploitation of mineral resources do not provide an alternative development route and that their arguments seem to suggest that developing countries would be better off leaving their natural resources undiscovered and/or unexploited. He posits, "What natural resources do to a country's productivity and growth prospects depends on the nature and type of the learning process involved in exploiting and developing them". In this regard, he agrees with Gavin Wright's (1990) suggestion that if natural resources are developed through advanced forms of knowledge development, their spillover effects may be just as powerful as anything done in any other sector, including manufacturing.

According to Matsen and Torvik (2003), while there is plenty of literature that explains why resource wealth may lower growth, little has been written on how resource wealth should be optimally managed 
to spur growth. In response to this gap of knowledge, they have developed an "optimal resource wealth savings and growth of consumption and output" model based on the assumption that even in the case where growth decreases, this may be the optimal response to resource abundance and that the optimal share of national wealth consumed in each period does not need necessarily to be adjusted down. The model stipulates that (a) some level of Dutch disease is needed; (b) the optimal spending path of the resource wealth may be increasing or decreasing over time; and (c) a positive fraction of the resource wealth should be consumed in each period to stimulate growth. Takizawa, Gardner and Ueda (2004) on their discussions on optimal fiscal policies and use of non- renewable resources, argue that when the initial capital stock is low, countries can be better off spending more of their mineral wealth upfront, if government spending has positive externalities. However, they also contend that where efficiency of government spending is low and institutions and infrastructure are weak and poor, spending should be postponed up to when mineral wealth can be used more effectively.

\section{To Mine or Not to Mine?}

Without getting caught up in the back and forth debate on the natural resource curse, this paper advocates that mineral resources can be exploited and managed to contribute to poverty reduction and growth in Africa. This position is premised on the recognition that mineral resources are part of the stock of natural capital that Africa has been richly endowed with, which, if exploited under appropriate conditions, can spur the development of the continent. The minerals, oil and gas sectors have been, and continue to be those that have attracted most foreign direct investment in Africa. For many African countries, mining and oil represent the largest sources of export earnings. Hence, as articulated by Davis and Tilton (2002) the appropriate public policy question is not whether to mine or not to mine, but where should mining occur and how to ensure that it contributes as much as possible to growth and poverty reduction.

However, it is also important to note that despite its impressive mineral resources endowment, Africa remains the poorest and the least developed continent in the world and that, overall, mineral resources revenue streams have not been used appropriately to foster development and industrialization of the continent. In most countries, linkages between the natural resources sector and other sectors of the economy are still weak. In addition, most development approaches and outcomes have been government-centred, with very little participation of stakeholders, including local communities affected by the exploitation of mineral resources. Where mining has contributed to better development outcomes, as is the case in Botswana, Morocco, Namibia and South Africa, success could be linked to sound management of the sector; good governance; respect for the rule of the law; good infrastructure; and an overall favourable environment for business development. On the opposite extreme and in a not so distant past, the cases of DRC, Sierra Leone and Liberia depicted lost opportunities, corruption, conflict and mismanagement of resources.

In articulating options to mainstreaming mineral wealth in growth and poverty reduction strategies, the different roles that large and artisanal/small-scale mining (See Table 1 and 2 respectively) can play in African economies need to be recognized. The former has potential to (i) generate foreign exchange and other mineral rents and fiscal receipts as windfalls to supplement local budgets and free financial resources that can be allocated for poverty reduction; (ii) contribute to local economic development through the provi- 
sion of basic infrastructure (roads, power grids, and dedicated ports), public goods and social services (water, health and education); (iii) facilitate skills and knowledge development and the creation of local human and social capital; and (iv) spur the development of minerals clusters comprising minerals goods and service inputs sector (e.g. capital equipment, consumables, contracting, consulting, etc), downstream processing and beneficiation industries, and centers of knowledge creation and innovation (technology incubation centers). The latter has potential to (i) create employment in rural areas; (ii) stem rural-urban migration; (iii) generate additional income to supplement local economies; (iv) be a precursor to major mines; (v) enable the exploitation of what would otherwise be uneconomic reserves; and (vi) provide a route to the creation of micro mineral clusters in rural areas.

There is also need to recognize that (i) mineral resources are finite and unevenly distributed; (ii) they are location-specific and must be exploited where they occur; (iii) mineral wealth is transitory; (iv) large-scale mining is often capital-intensive rather than labour-intensive; and (v) political, social, economic, cultural and environmental consequences and impacts (Table 1 and 2) of mineral exploitation are difficult to manage and overcome. It is therefore important to understand these attributes of mineral resources, the daunting public policy challenges that they pose, as well as the limitations that they impose on policy makers and other stakeholders. These challenges are linked to:

- Creating a viable, integrated and diversified mining industry throughout the value chain, and sustaining mineral wealth without compromising environmental, social and cultural considerations, and ensuring a regulatory framework that encourages mineral creation (the creation challenge).

- Investing transitory mineral revenues to ensure lasting wealth and deciding how much ought to be saved and how much should be invested and in what (the investment challenge).

- Distributing benefits from mining equitably, balancing and managing conflicting local and national-level concerns and interests and deciding what form the allocation should take to promote pro-poor growth (the distributional challenge).

- $\quad$ Ensuring sound systems of governance and a stable macroeconomic policy, which curbs rent seeking and corruption, addresses issues such as the Dutch Disease and externalities such as unstable commodity prices, and enhances public interest in wealth conservation (the governance and macro-economic challenges).

\section{Options for Africa}

This paper contends that where economics, social and environmental considerations justify, mineral resources should not be left on the ground. Instead, they should be exploited judiciously, using the highest corporate, social and environmental standards to ensure better development outcomes. Because mineral resources are finite, mineral wealth should be invested to create new wealth and used to create forms of renewable capital, such as human, social and physical capital, which are key to achieving sustainable development beyond the currency of mining. Also key is to develop minerals clusters and to create opportunities for growth of lateral or downstream businesses that have the potential to create more employment and generate valued-added rents and wealth. In countries where mining is an important, if not the dominant 
sector of the economy, or has potential to be so, strategies to address the creation, investment, distributional, governance and macroeconomic challenges of mineral resources management earlier described and to mainstream mineral wealth into growth and poverty reduction in Africa should thus centre on:

- $\quad$ Creating a conducive, stable and predictable policy, legal and regulatory framework and a competitive fiscal regime with a view to attracting and retaining the required level of investment in the sector, creating wealth, promoting employment and opening-up opportunities.

- Achieving better mineral resources revenue allocation and redistributing the benefits ${ }^{5}$ of mineral wealth through improvements in the governance and management of revenue flows deriving from mining, and through decentralization of decision-making and resource allocation.

- $\quad$ Promoting a calculated, parsimonious and well-informed spending, savings and investment (in other assets) strategy, which prioritizes human, social and physical capital creation and transformation of mineral wealth into financial assets that yield higher returns (the annuity policy).

- $\quad$ Promoting mineral resources revenue stabilization and reducing fiscal imbalances through greater fiscal discipline, certain level of fiscal conservatism and increased capacity for forecasting and managing mineral revenues with a view to reducing uncertainties about their magnitude, mitigating market externalities and minimizing adverse macro-economic impacts associated with commodity price fluctuations.

- Enhancing governance systems, organizational and institutional capacity in sectoral ministries, in the ministries of finance and planning, and in local governments.

- $\quad$ Forging tri-sector partnerships and creating coalitions of change (Steele, 2004) between public, private (mainly mining companies) and local stakeholders to improve community livelihoods and to maximize other socio-economic and development outcomes.

- $\quad$ Empowering communities in mining regions to be able to make informed decisions and to better participate in their own development.

- Unbundling the sector and promoting a strategy that encourages local procurement and outsourcing of goods and services, value-addition and local beneficiation of minerals, diversification from minerals, as well as optimizes business multipliers and enhances linkages between mining and other sectors of the economy, including at local community level.

- Encouraging mining companies to behave in a more social and corporate responsible manner with a view to improving the social relevance of mining.

The strategies described above are general in nature. To render them relevant, their application should be context and country specific, taking into consideration local capacity and resources (financial, technical and above all human skills and knowledge), as well as constraints. To be effective, the policies should be part of an overall poverty reduction and growth strategy and should be mainstreamed in comprehensive and sound Poverty Reduction Strategy Papers (PRSPs) or other development plans. To better capture and factor the mining dimension and variables in the PRSPs, there is need to adequately profile the mining sector and to develop a thorough understanding of the positive and negative impacts of mining (See Tables 1 and 2) for poverty reduction and growth promotion. 


\section{Table 1: Linkages between Large-scale Mining and Economic Growth and Development}

\begin{tabular}{|c|c|c|}
\hline Economic Impacts & Positive Impacts & Negative Impacts \\
\hline \multirow[t]{3}{*}{ Macro Economic. } & Fiscal flows. & Potential for Dutch Disease. \\
\hline & Foreign exchange generation. & $\begin{array}{l}\text { Poor governance of key economic factors such as exchange rates } \\
\text { and interest rates. }\end{array}$ \\
\hline & Significant economic multipliers. & $\begin{array}{l}\text { Cyclical commodity price impacts on an unbalancedeconomy } \\
\text { where there is heavy dependency on minerals. }\end{array}$ \\
\hline \multirow[t]{5}{*}{$\begin{array}{l}\text { Economic } \\
\text { Development. }\end{array}$} & $\begin{array}{l}\text { Associated economic and tertiary devel- } \\
\text { opment. }\end{array}$ & $\begin{array}{l}\text { Sudden end of economic opportunities and employmentin the } \\
\text { context of mine closure. }\end{array}$ \\
\hline & $\begin{array}{l}\text { Significant opportunities for SME devel- } \\
\text { opment. }\end{array}$ & \\
\hline & Upstream and downstream opportunities. & $\begin{array}{l}\text { Competing for resources (land, water, infrastructure) can create } \\
\text { barriers in other economic sectors. }\end{array}$ \\
\hline & Job creation. & $\begin{array}{l}\text { Contractions of mining activity can create majorunemployment in } \\
\text { an undiversified economy. }\end{array}$ \\
\hline & $\begin{array}{l}\text { Mining infrastructure and related second- } \\
\text { ary and tertiary industries catalyse and } \\
\text { create an enablingenvironment for cross } \\
\text { sectoral development. }\end{array}$ & $\begin{array}{l}\text { Income security of non-mining activities compromisedby increases } \\
\text { in income resulting from high-incomelevels for miners. }\end{array}$ \\
\hline \multirow{3}{*}{$\begin{array}{l}\text { Socio-economic } \\
\text { Factors } \\
\text { Infrastructure } \\
\text { Development. }\end{array}$} & Physical. & $\begin{array}{l}\text { Dependency on mining related infrastructure leads to collapse of } \\
\text { infrastructure with mine-closure. }\end{array}$ \\
\hline & Social. & $\begin{array}{l}\text { Rapid change in the economic and social fabric of society. Threats } \\
\text { to indigenous land rights and usufruct on infringementby powerful } \\
\text { mining companies. Social tensions and local price inflation due to } \\
\text { large migration of job seekers Conflicts between original residents } \\
\text { and newcomers.Substance abuse, prostitution, HIVIAIDS and } \\
\text { STDs. }\end{array}$ \\
\hline & $\begin{array}{l}\text { Industrial. } \\
\text { Commercial. } \\
\text { Administrative. }\end{array}$ & $\begin{array}{l}\text { Government tendency to leave service delivery to mining compa- } \\
\text { nies exacerbates community dependency onmining infrastructure } \\
\text { and services. }\end{array}$ \\
\hline \multirow[t]{2}{*}{ Skills Development. } & Life skills. & $\begin{array}{l}\text { Work-related health risks, widespread HIV, alcoholism, and related } \\
\text { gender issues. }\end{array}$ \\
\hline & Vocational skills. & Over reliance on non-transferable mining skills. \\
\hline \multirow[t]{5}{*}{ Empowerment. } & Economic empowerment. & Corruption: Benefit of mining diverted for personal /political gain. \\
\hline & Political empowerment. & $\begin{array}{l}\text { Risks to political stability - mineral revenues fund } \\
\text { conflict;competition for mineral resources fuels politicaland civil } \\
\text { conflict. }\end{array}$ \\
\hline & $\begin{array}{l}\text { Presence and development of local gov- } \\
\text { ernmentCapacity. }\end{array}$ & $\begin{array}{l}\text { High level of corruption can keep the poor further excludedfrom } \\
\text { decision-making processes. }\end{array}$ \\
\hline & $\begin{array}{l}\text { Community capacity through consultative. } \\
\text { partnerships with NGOs and mining com- } \\
\text { paniesbuilding reduces vulnerability. }\end{array}$ & $\begin{array}{l}\text { Development of culture of dependence on mining incomes and } \\
\text { infrastructure. }\end{array}$ \\
\hline & & $\begin{array}{l}\text { Local communities often excluded from planning and decision } \\
\text { making processes on issues of fundamental importance to their } \\
\text { interests. }\end{array}$ \\
\hline \multirow[t]{4}{*}{ Social Security. } & Security of food supply. & Development of community dependence on mining incomes. \\
\hline & Shelter. & Dependence on mining accommodation and infrastructure. \\
\hline & Health care. & Increase in disease vectors sp. HIVIAIDS. \\
\hline & Crime prevention and control. & $\begin{array}{l}\text { Increase in local money flow in mine dependent communities } \\
\text { encourages crime. }\end{array}$ \\
\hline \multirow[t]{2}{*}{$\begin{array}{l}\text { Environmental } \\
\text { Impacts }\end{array}$} & $\begin{array}{l}\text { Economic empowerment reduces the } \\
\text { impact ofpoverty on the environment. }\end{array}$ & $\begin{array}{l}\text { Inter-sectoral competition for critical natural resourcesand infra- } \\
\text { structure. }\end{array}$ \\
\hline & $\begin{array}{l}\text { Deforestation for domestic fuel, charcoal } \\
\text { making,land clearance for subsistence } \\
\text { farming,overgrazing, water pollution. }\end{array}$ & $\begin{array}{l}\text { Environmental risks and impacts on health and } \\
\text { environment(tailings, toxic waste, waste management, water, soil } \\
\text { andair pollution, dust, land disturbance, deforestation). }\end{array}$ \\
\hline
\end{tabular}

Source: Modified from Solomon, Michael H (2004) 
Table 2: Linkages between Small-scale Mining and Economic Growth and Development

\begin{tabular}{|c|c|c|}
\hline Economic Impacts & Positive Impacts & Negative Impacts \\
\hline Micro-economic. & & $\begin{array}{l}\text { Large scale smuggling of high value SSM product (gold, } \\
\text { diamonds, tanzanite, coloured gem stones)escapes fiscal net and } \\
\text { erodes foreign exchange earnings. }\end{array}$ \\
\hline \multirow[t]{6}{*}{$\begin{array}{l}\text { Economic } \\
\text { Development. }\end{array}$} & $\begin{array}{l}\text { SSM offers the lure of higher } \\
\text { incomesthan from alternative } \\
\text { subsistence activities(farming, fishing). }\end{array}$ & Income tends to be highly seasonal.. \\
\hline & $\begin{array}{l}\text { Important source of cash in rural } \\
\text { areas.SSM is often a critical economic } \\
\text { activityfor women. }\end{array}$ & $\begin{array}{l}\text { Competition for natural resources (land and water)by incoming } \\
\text { groups of small-scale miners cancompromise income generation } \\
\text { opportunities for othersubsistence economic activities. }\end{array}$ \\
\hline & Employment generation. & $\begin{array}{l}\text { Small-scale miners can lose property and incomewhere mining } \\
\text { rights are not regulated or protected. }\end{array}$ \\
\hline & $\begin{array}{l}\text { Local cash economy catalyses } \\
\text { rapidSME development and creates } \\
\text { local economic multipliers. }\end{array}$ & $\begin{array}{l}\text { Lack of financial resources by small-scale minersresults in highly } \\
\text { exploitative practices bycommodity buyers, who advance money } \\
\text { to miners on extortionate terms. }\end{array}$ \\
\hline & $\begin{array}{l}\text { The SSM“barons" typically re-invest their } \\
\text { earnings in alternative activities such as } \\
\text { shops, taxis, bars, and guesthouses etc. } \\
\text { creatinglocal economic diversification. }\end{array}$ & $\begin{array}{l}\text { Domination of local economy by SSM "barons"can lead to highly } \\
\text { exploitative practices negativelyimpacting on the poor. }\end{array}$ \\
\hline & $\begin{array}{l}\text { Artisanal miners are excellent } \\
\text { prospectorsand can identify deposits } \\
\text { outside of expensive government or } \\
\text { private sector explorationprogrammes. }\end{array}$ & \\
\hline \multicolumn{3}{|l|}{$\begin{array}{l}\text { Socio-economics } \\
\text { Factors }\end{array}$} \\
\hline $\begin{array}{l}\text { Infrastructure } \\
\text { Development. }\end{array}$ & & $\begin{array}{l}\text { While artisan communities can rapidly develop nd grow, there } \\
\text { is seldom government support for these informal communities. } \\
\text { Lack of infrastructurecauses major health and social problems. }\end{array}$ \\
\hline Skills Development. & & $\begin{array}{l}\text { Lack of formal mining skills leads to highlydangerous workplace } \\
\text { practices and highlyinefficient mining methods and resource } \\
\text { utilisation. }\end{array}$ \\
\hline \multirow[t]{4}{*}{ Empowerment. } & & $\begin{array}{l}\text { Indigenous groups are compromised by exclusionfrom decision } \\
\text { affecting their land and their property rights. }\end{array}$ \\
\hline & & $\begin{array}{l}\text { Indigenous communities with traditional land rightsare powerless } \\
\text { to stop rushes of artisanal miners. }\end{array}$ \\
\hline & & $\begin{array}{l}\text { Artisanal miners are generally excluded frompublic decision- } \\
\text { making process because of the absence of local government } \\
\text { structures. }\end{array}$ \\
\hline & & $\begin{array}{l}\text { Artisanal mining is largely an unregulated environment, which is } \\
\text { to the detriment of the greater community and economy. }\end{array}$ \\
\hline \multirow[t]{6}{*}{ Social Security. } & & Invasion of lands of indigenous or tribal peopleby miners. \\
\hline & & $\begin{array}{l}\text { Risk of severe cultural conflicts between minersand local or } \\
\text { indigenous population. }\end{array}$ \\
\hline & & $\begin{array}{l}\text { If diamonds; risk of illegitimate diamond tradingto contribute to } \\
\text { finance regional conflicts. }\end{array}$ \\
\hline & & $\begin{array}{l}\text { Lack of health care and education facilities inartisanal mining } \\
\text { communities highly problematic. }\end{array}$ \\
\hline & & $\begin{array}{l}\text { Widespread use of child labour has highly negativeimpacts on } \\
\text { health and education. }\end{array}$ \\
\hline & & $\begin{array}{l}\text { Work-related health risks as well as widespreadHIV, alcoholism } \\
\text { and related issues. }\end{array}$ \\
\hline \multirow[t]{5}{*}{$\begin{array}{l}\text { Environmental } \\
\text { Impacts. }\end{array}$} & & Massive physical damage. \\
\hline & & Mercury pollution. \\
\hline & & $\begin{array}{l}\text { Extensive deforestation for mining support, fuel for artisanal } \\
\text { mining communities and charcoalsupply to these communities. }\end{array}$ \\
\hline & & Community health. \\
\hline & & Disease vectors. \\
\hline
\end{tabular}

Source: Modified from Solomon, Michael H (2004) 
Apart from the broad objectives discussed above, the following five specific goals deserve special mention and further consideration:

\section{Improving Public Participation in Mineral Resources Development}

Given the current societal-oriented development paradigm, the paper advocates that the development of mining should be people-centred and not only profit-motivated. In this quest, new partnerships, conscious of the need for change, are emerging and being built between governments, the corporate world, civil society, local communities and other stakeholders. Guidelines, protocols, codes of practice, organizational policies and management systems, voluntary undertakings and statements of principle are being drafted and enforced to help effect this transition and improve the social and development outcomes of mining at the local level.

However, more needs to be done to achieve change. Policies, legal and regulatory frameworks to facilitate equitable participation by local businessmen, communities and other stakeholders in mining activities should be in place, as well as tools to improve revenue (derived from royalties, income taxes, land taxes, lease rents, etc) distribution at local level. Many examples of these new approaches abound (ECA, 2004). The key areas that they aim to address are:

(i) Preferential employment of local labour;

(ii) Contracting of services and procurement of goods from indigenous local companies;

(iii) Infrastructure provision to local communities;

(iv) Allocation of benefits from mining to local communities;

(v) Local community allocation of national revenue; and

(vi) Community equity participation.

Because each country is different and specific, the approaches described below should serve only as references. In developing a framework for facilitating public participation at country level, there is need therefore to consider and factor in the local context and peculiarities.

- The Papua New Guinea Act of 1992, which stipulates that a minimum of 20\% of royalties received by the government, should be paid to landowning communities of the mining lease area (In this case royalties are paid directly by mining companies to the agreed beneficiaries and then reconciled to central government for audit).

- Special Support Grants (also in Papua New Guinea) paid to a given provincial government, which represent about $1 \%$ of the gross value of mineral sales of companies operating in the said province.

- $\quad$ Preferred Area Status (also in Papua New Guinea), which requires companies to provide preferential treatment in terms of employment, education and training and business development assistance to communities located in the area in which the company mines.

- The holding of mineral rights to platinum and other resources in the Merensky Reef in Northwest South Africa by the baFokeng tribe. The tribe is a shareholder in the Impala Platinum Holdings Ltd, which is the second largest producer of platinum in the western world. 
The company has four mines, namely baFokeng North and South and Wildebeestfontein North and South.

- Local impact and benefits agreements (IBAs) involving mining companies, government and communities where mining development occurs within traditional aboriginal lands or remote communities in Canada. The IBAs can range from ensuring employment and training of members of the local community to equity participation and profit sharing.

- The "Scorecard for the Broad-based Socio-economic Empowerment Charter for the South African Mining Industry”, which sets targets for South African mining companies to transform the face of the mining industry in the country in terms of human resources development; employment equity; migrant labour; mine community and rural development; housing and living conditions; procurement; ownership and joint ventures; beneficiation; and reporting.

To empower local communities to effectively and meaningfully participate in the mineral resources development in their constituencies, there is need to capacitate them through training and improvement of their rights of access to information. Participation should also be extended to policy formulation and planning and monitoring of project implementation. Environmental impact and social assessments should be mandatory for all project approval processes.

\section{Mainstreaming Mining in PRSPs}

The World Bank sourcebook on "Mining and Poverty Reduction" (Weber-Fahr, et al, 2001) provides a comprehensive framework and guidelines on how to integrate mining in PRSPs. However, as noted by many scholars, the current series of PRSPs and Interim Poverty Reduction Strategy Papers (I-PRSPs) in Africa and other developing countries either ignore mining or accord it a fleeting mention with inadequate sector profiling. In addition, the potential contribution of mining to poverty reduction has not been well factored or reflected in the PRSPs and I-PRSPs, even in mineral economies.

As Elisabeth Stites (2003) points out, most PRSPs and I-PRSPs do not indicate how revenues from mining will be used to alleviate poverty, and they do not establish any clear link between investment in the sector and the reduction of poverty. Also, while many countries focus on the extractive sector as a major source of growth, they appear to assume a simple and linear path between economic expansion and poverty reduction. The PRSPs and I-PRSPs do not contain policies or regulatory guidelines to ensure the allocation of financial resources from mining towards priority sectors or pro-poor growth, and fail to stress the fact that growth must be channelled into pro-poor initiatives in order to achieve poverty reduction. Lastly, Stites notes that many PRSPs and I-PRSPs fail to underscore the negative economic, political or social externalities and pitfalls that may potentially arise from a growth strategy that relies solely on mining and lack of awareness of the potential for resource-dependent growth to exacerbate poverty. In view of these, most PRSPs and I-PRSPs of African mineral economies must now be thoroughly reviewed to address those shortcomings.

The shortcomings may be attributed to policy failures, lack of political will, minimum capacity (knowledge gaps, insufficient financial and human resources) in government institutions, hastily-prepared PRSPs 
and I-PRSPs and poor understanding and uninformed perceptions about the sector, stemming from lack of data on the overall importance and impact of the sector, in particular on (i) sustainability and vulnerability in mining dependent communities (household income and economics); (ii) demographics of mine labour; (iii) direct and indirect cash flows (wages, mineral rents, corporate taxes and other rates and levies, profits and purchases) into communities, local and national governments; (iv) patterns of procurement of goods and services; (v) contribution to physical, human and social capital creation; and (vi) time span of mine derived benefits vis-a-vis the mine life cycle. The need for robust and good quality data on mining economics and impacts at local, national and sub-regional levels could not be overemphasized. African governments and international agencies should therefore deploy efforts to collect and collate this essential data.

As indicated in the World Bank framework, when integrating mining into PRSP or I-PRSPs, policy-makers should focus on:

- Gathering relevant data to understand actual and potential poverty-related impacts, risks, and opportunities of the mining sector in their country;

- $\quad$ Setting clear objectives and identifying priorities for intervention in a consultative process regarding poverty impacts and the mining sector;

- Identifying the mechanisms to achieve the objectives, including needed changes in policies, laws and regulations; and

- $\quad$ Establishing the necessary institutional arrangements, including authorities, responsibilities and capabilities to implement the mechanisms.

In preparing the PRSPs there is need to foster broad consultation and participation through the involvement of local community representatives, local government representatives from mining regions, industry associations, trade unions, non-governmental organizations (NGOs), and other relevant parties. In most cases, the Ministry responsible for mining is better placed to lead the process. In addition, the inputs and participation of medium-and large-scale mining private companies should be sought as they have resources and expertise that can play a vital role in creating sustainable development opportunities within the currency of mining and after it.

\section{Improving Management of Mineral Revenue: The Case of Stabilization Funds and Non-renewable Resource Funds (NRFs)}

A cause of major concern in managing mineral revenue is the price volatility of mineral commodities and its impact on local budgets. Uncertainty in revenue collection mostly due to commodity price fluctuations, has led many to advocate the use of stabilization funds as a means to achieving fiscal stability and discipline. Although it can be argued that these funds apply more to the oil and gas sectors due to the sheer magnitude of the revenue flow accrued to producing countries, the same concept and principles could also apply to the minerals sector. In addition, tools such as commodity loans, bonds, swaps, and derivative markets such as futures, forwards and options should be considered as solutions to managing revenue volatility and hedging against exposure to commodity price risk for short- and long-term horizons. 
NRFs, including future generation funds, have been established in several countries (Daniel, P., 2002) as a tool to insulate economic activities from fluctuations in mineral resources revenue (stabilization motive); save wealth for future use on grounds of inter-generational equity (savings motive); and manage uncertainty on the likely path of future mineral revenues or on the ability of the economy to absorb spending efficiently (precautionary motive). For example, as part of the conditions for developing the Chad oil fields and funding the Chad-Cameroon oil pipeline, and in an effort to prevent waste and corruption and promote transparency in the use of oil revenues, the World Bank imposed the establishment of such a fund in the two countries.

However, as it has been clearly illustrated in the case of Nauru (See Box 1), these funds are not a panacea to wasteful use of mineral rents. To ensure that they contribute to improving fiscal discipline, fostering transparency in the management of mineral-derived savings as well as promoting equitable share of benefits between national, regional and local stakeholders, there is need to promote good governance. In establishing them, it is, therefore, important to ensure that an independent, accountable and capable body manages the funds. It is also essential that information about how mineral revenue is used is publicly available and timely disseminated to all stakeholders.

Of equal concern is the management of the effects of the Dutch Disease. Several strategies should be considered including:

- Using conservative price estimates in budgeting;

- Channeling export windfalls into stabilization funds to reduce the impact on domestic income and on the real exchange rate;

- Using appropriate monetary intervention (e.g. sterilization of receipts) and appropriate fiscal policies to curb over-heating in the economy and to prevent inflation;

- $\quad$ Allocating increased income into productive investment in other sectors and financial assets; and

- Using sound and tight fiscal policies and management (e.g. constraining liquidity; consolidated budget framework; and restraining public sector spending).

\section{Fostering Minerals Cluster ${ }^{6}$ Development}

Mineral resources driven diversification strategies or resource-based industrialization (RBI) are not a new mantra. The vision that mineral resources could be used to catapult Africa to modernization has been articulated in many African plans and development strategies (Africa Mining Ministers Forum, 2003) at national and regional levels (e.g. Lagos Plan of Action, SADC Mineral Sector Programme, Mining Chapter of NEPAD, and, most recently, the Africa Mining Partnership). However, most of those plans and strategies failed. They were centred in developing ambitious and grandiose projects (e.g iron and steel mill in Ajaokuta, in Nigeria) designed with a very narrow "mining box" mentality and limited to the initial mineral resource factor endowment. The projects were very capital intensive and dependent on foreign inputs. Reasons for failure include (i) inefficiency and poor management; (ii) projects not imbedded in the local economy; (iii) tariff escalation, trade barriers and other market imperatives; (iv) lack of 


\section{Box 1: Phosphate mining in Nauru: An example of bad investments}

Nauru is a $21 \mathrm{sq}$ meter island state in the South Pacific Ocean. Nauru's phosphate deposits began to be mined early in the $20^{\text {th }}$ century by a German-British consortium. At their peak, revenues totaled $\$$ US 1 billion, and in the 1980s and early 90s, Nauru boasted one of the highest per capita incomes in the world. However, the consequences of intensive mining during the past 90 years have been very bad. $90 \%$ of the island has been reduced to a barren moonscape and an unfarmable wasteland, which threatens limited, remaining land resources. There is no arable land, no crops and no woodland. The stock of fish has been reduced significantly; food and bottled water has to be imported. There is little employment in the island and Nauruans are now poverty-stricken and unhealthy. They have one of the highest rates of obesity and diabetes in the world and life expectancy has dropped to 55 years. Phosphate reserves are close to exhaustion. In anticipation of this, phosphate export royalties have been invested in offshore Trust Funds to help cushion the transition and provide for Nauru's economic future. Unfortunately, declining reserves of phosphate and decreasing prices led to shortfalls in revenue. The deficit grew to $18 \%$ of GDP by 2000 . The Government has been borrowing heavily from the trusts to finance its fiscal deficits. For example, in 2003 , Nauru had no budget and the country slumped into chaos. Now the island is reportedly a major center for offshore banking and money laundering. Some of the operations closed recently. More than \$US $1 \mathrm{bn}$ was invested in property around the Pacific Rim, equity in a range of businesses and in many ill-advised financial schemes. Little investment was done in the local economy and local people were not consulted on the investment done elsewhere.

Source: Modified from $B B C, U K$

capacity to innovate due to weak local knowledge; (v) lack of supporting infrastructure; and (vi) lack of competition.

The minerals cluster development strategy advocated in this paper is one that covers the full development spectrum i.e. from the macro, meso to the micro cluster level. In this regard, even small-scale mining has the potential to engender multiplier effects and spillovers at local, community and rural levels. The strategy looks at broadening the economy base and developing linkages between mining and other sectors at the upstream, backstream and sidestream value chain ladder and at maximizing development and social outcomes.

It includes all industries and services that gravitate to mining, such as financial services, transport, communication, energy, water, engineering and design, other consultancy services, knowledge and R\&D centres, providers of capital goods and consumables. The key outcomes would be:

- Increasing local upstream support (supplier/input industries) sectors;

- Enhancing downstream industries based on increased local beneficiation and value addition of goods;

- $\quad$ Facilitating lateral migration of mining technologies to other industries;

- Increasing social, human, knowledge and institutional capital (which can be used in other sectors); 
- $\quad$ Promoting the development of sustainable livelihoods in mining communities; and

- $\quad$ Creating small-and medium-sized enterprises and a more balanced and diversified economy with greater multiplier effects and potential to create employment.

This approach is based on the concept of integrated spatial and social development where the mining activity serves as an anchor to develop diversified and alternative activities that would be sustainable after the life of the mine. Successful clusters of this type have been developed in South Africa (gold and aluminium industry), Canada, Australia and the Scandinavian countries (ECA, 2004).

For this concept to be brought to fruition, it is important to have a shared strategic vision, deliberate, purposeful and proactive collective action (with governments taking the lead), timely interventions and coordination of public, private and community interests at all levels. There is a need to identify, at national and regional levels, areas where such clusters could be developed and devise strategies to facilitate project implementation. The role of regional cooperation and integration in reducing transaction costs, establishing intra-regional synergies, enhancing competitiveness and realizing economies of scale that would catalyse mineral cluster development should not be underestimated. However, for goods, services, capital and other factors to freely flow in the regional spaces, there is need to expedite intra-regional harmonization of laws, regulations and fiscal regimes. Other critical factors that can spearhead minerals cluster formation include:

- $\quad$ Availability and further development of a local skills base;

- $\quad$ Adequate infrastructure;

- $\quad$ Existence of a critical mass of companies and institutions willing to cooperate, network and share knowledge and information formally (e.g. through industry associations such as Chambers of Mines) and informally;

- Combination of legal requirements and incentives that encourage local outsourcing of goods and services;

- $\quad$ Provision of financial support for the development of small-and medium-scale mining supply and services companies;

- $\quad$ Existence of hives of research and development, innovation, diversification and technology diffusion;

- Establishment of targeted human resources development programmes and technical support systems; and

- $\quad$ Establishment of effective marketing channels, which can improve demand.

\section{Improving Sustainability in Artisanal and Small-scale Mining (ASM) Communities}

Increasing numbers of people have turned to small-scale mining to seek alternative livelihoods. The contribution of this sub-sector to income generation and employment creation, especially in rural areas, is not negligible ${ }^{7}$. ASM has also helped reduce migration of the youth from rural to urban areas. ASM also has the potential to catalyze SME development and to foster local economic multipliers and micro 
mineral cluster formation. However, the sector is plagued with many problems, including isolation from the mainstream of economic development, environmental degradation, and sub-optimal exploitation of resources due to use of rudimentary technology, health and safety hazards, and crime.

Many of the problems besetting ASM may be associated with limited capacity, assets and entitlements (e.g. insecurity of tenure on mining titles) of ASM communities. In this regard, the paper proposes the adoption of a pluralist, holistic and multi-pronged approach that goes beyond providing technology options to make small-scale mining a viable activity. The approach is based on the provision of affordable/ accessible technology to small-scale miners, formalization of the sector and the development of diversified and alternative livelihoods to ASM (artisan training on alternative skills such as carpentry and brick laying, diversifying income sources and broadening non-mining incomes). This should result, respectively, in some miners abandoning mining altogether; fewer miners per unit of area mined; more income for the remaining miners; and ultimately less pressure on the limited resources.

The Yaounde Vision ${ }^{8}$ on ASM provides a good framework for the development of the sub-sector in Africa. The Vision recognizes ASM as a poverty-driven activity and recommends that it should be integrated in PRSPs of African governments. It further urges that the mining policies and laws of member States should be reviewed to incorporate a poverty reduction dimension in ASM strategies. Equally important is the framework provided by the Strategic Plan (2004-2006) of the Communities and Artisanal and Smallscale Mining $(\mathrm{CASM})^{9}$, the global forum for knowledge sharing and coordination between the various institutions working on ASM. CASM's vision on ASM is one that:

- Advances integrated rural and regional social and economic development;

- $\quad$ Functions within an equitable and effective legal framework;

- Establishes positive, productive relationships with local communities, as well as large-scale mining companies and government agencies;

- Utilizes environmental responsible techniques;

- Complies with international standards related to child labour and occupational health and safety;

- $\quad$ Provides an acceptable income through increasingly productive mining and processing practices;

- $\quad$ Allows for long-term efficient resource extraction;

- Accesses fair markets and sources of credit; and

- Enhances local infrastructure and services.

There is therefore need to mitigate environmental, social and economic impacts that create poverty in ASM communities; integrate ASM into local and regional economic development and land-use planning; promote cooperation for constructive change and build synergies between ASM and large-scale mining; and provide training to small-scale miners in analytical skills, sound business and management culture, capabilities and practices. This will help to scale ASM up and to facilitate its transformation from a transitory and shock-or-coping-responsive activity into a serious business venture and to change ASM communities from vulnerable and marginal enclaves of unorganized groups of miners and other actors into integrated and functionally sustainable and resilient communities. 


\section{Conclusion}

Available statistical evidence shows that mineral economies are diverse (in terms of geography, per capita income, growth, life expectancy, and adult literacy). Some mineral-rich nations have high growth rates; others have negative growth. Some nations are the poorest in the world; others are the richest. Furthermore, data show that there is nothing inherent in mineral resource abundance that condemns countries to either growth or non-sustainability. Therefore, poor performance is not inevitable. It is possible to reconcile mining with the objectives of equitable growth and development, and poverty reduction while observing the highest environmental management and social standards. Heterogeneity accepted and idiosyncrasies considered, there is scope for African countries to learn from and emulate successful examples like Botswana, where mining has played a pivotal role in the growth and development of the country.

Good governance is a fundamental prerequisite to turn Africa's mineral endowments into a blessing that can promote growth and poverty reduction. There is need to shift from resource extraction to resources management. This is not easy to achieve, for there is no easy panacea or universal recipe. The resource curse is a force that cannot be ignored.

Because mining does not happen in isolation, the overall context of any country's economy management and strength of institutions play an important role on the fate of mining. Therefore, for mining to play a more seminal role in African economies there is need at country level for an overall transformation in business and financial organization, education, research and knowledge development, human capital accumulation and infrastructure expansion. This is at the core of the minerals cluster concept advocated in the paper. This can be facilitated in an environment of well-developed and stable political institutions that respect the rule of law, markets and private enterprise. In the African context, to achieve this is a daunting task.

Other key requirements to mainstreaming mining into growth and poverty reduction are good mineral policies, laws and regulations and a balanced fiscal regime that promotes the creation of mineral wealth. In addition, to promote equity and fair distribution of the benefits of mining, there is need to enhance transparency, accountability, over-sighting and monitoring in the management of mineral revenue flows and decentralization of revenue sharing. Furthermore, the industry needs to be unbundled because increased local beneficiation and value addition, and local procurement and outsourcing of goods and services would help diversification and creation of more employment and value added rents and wealth. Governments have to play a proactive role in this effort.

Sustainability of mining can be enhanced if mineral wealth is invested during the currency of mining on human and social capital creation and partly on an income-generating portfolio of financial assets that yield higher returns than mining. Development outcomes of mining can be also enhanced if coalitions of change with increased, informed and meaningful participation of local communities and other stakeholders in the decision-making and implementation of extractive industry projects are promoted. This should be coupled with better understanding and factoring of local context and specificities and better integration of mining in local economies, development plans and poverty reduction strategies (e.g. PRSPs). 
For this to be done efficiently, there is need to strengthen institutional capacities and competencies (at government and other levels) for efficient long-term planning for sustainable development, prudent management and smart spending, savings and investments of mineral wealth. 


\section{References}

African Mining Ministers Forum (2003), Final Communiqué, Mount Nelson Hotel, Cape Town, South Africa

Ahammad, Helal and Clements, Kenneth (1999), What Does Minerals Growth Mean to Western Australia? Resources Policy, Vol. 25, p.p. 1-14

Auty, Richard M. (1991), Sustaining Development in Mineral Economics: The Resource Curse Thesis, London, Routledge

Auty, Richard M. (1998), Mineral Wealth and the Economic Transition: Kazakstan, Resources Policy, Vol. 24, pp. 241-249

Auty, Richard M. and Mikesell, Raymond F. (1999), Sustainable Development of Mineral Economies, Clarendon University Press. Oxford

Auty, Richard M. (2001), The Political Economy of Resource-Driven Growth, European Economic Review, Vol. 45, Nos 4-6, pp. 839-846

Burke, Edmund and Mitchell, L.G. (Editor), Reflections on the Revolution in France, Oxford University Press (August 1993) http://www.conservativeforum.org/EssaysForm.asp?ID=6230, accessed on $11 / 2 / 2004$

Clements, Kennet W. and Johnson, Peter L. (2003), The Minerals Industry and Employment in Western Australia: Assessing its Impacts in Federal Electorates, Resources Policy, Vol 26, p.p.77-89

Campbell, B. (2003), African Mining Codes Questioned, Mining Journal, February 14, p.p. 106-109.

Campbell, B. (2003), Factoring in governance is not enough. Mining codes in Africa, policy reform and corporate responsibility, Minerals \& Energy, Raw Materials Report.

Cheney, H.; Lovel, R; and Solomon, F. (2001), People, power, participation: a study of mining - community relationships, Mining, Minerals and Sustainable Development Project

Daniel, P (2002), “ Petroleum Revenue Management; pp 34, An Overview, prepared for the World Bank, ESMAP Program

Davis, Graham and Tilton, John E. (2002), Should Developing Countries Renounce Mining? A Perspective on the Debate, Colorado School of Mines, Denver, Colorado 
Davis, Graham (1998), The Minerals Sector, Sectoral Analysis, and Economic Development, Resources Policy, Vol. 24, No. 4, p.p. 217-228

ECA (2003), Training Materials on "The Role and Management of Mineral Wealth in Socio-economic Development"(Unpublished), Addis Ababa, Ethiopia

ECA (2004), Minerals Cluster Policy Study in Africa: Pilot Studies of South Africa and Mozambique (Unpublished), Addis Ababa, Ethiopia

ECA (2004), Improving Public Participation in the Sustainable Development of Mineral Resources in Africa (Unpublished), Addis Ababa, Ethiopia

ECOSOC (1998), Issues Related to the Social and Economic Impacts of the Mining Sector, Especially in Developing Countries and Economies in Transition: Basic Problem of Improving the Capacity of Developing Countries and Economies in Transition to Capture the Maximum Economic and Social Benefits of their Potential for Mineral Production (Report of the Secretary General)

EIR (2003), EIR Final Report: Striking a Better Balance, http;//www.eireview.org/html/EIRFinalReport. html, assessed on 20 July 2004

Goodland, Robert (2002), How to Ensure Extractive Industries Reduce Poverty and Promote Sustainable Development (Discussion paper commissioned by EIR), www.eireview.org

ICMM (2002), Spreading the Wealth: The Role of the World Bank Group in Mining, (ICMM Submission to the World Bank Group Extractive Industries Review), www.icmm.com

ILO (1999), Social and Labour Issues in Small-scale Mines, (Report for discussion at the Tripartite Meeting on Social and Labour Issues in Small-scale Mines, Geneva, 17-21 May 1999)

Lane, Phillip and Tornell, Aaron (1995), Power Concentration and Growth, Harvard Institute of Economic Research Discussion Paper, No.1720

Matsen, E. and Torvik, R. (2003), “Optimal Dutch Disease”, Working Paper Series No. 1/2003, Department of Economics, Norwegian University of Science and Technology, Trondheim, Norway

Mikesell, Raymond F. (1997), Explaining the Resource Course, with Special Reference to Mineral Exporting Countries, Resources Policy, Vol. 23, No. 4 pp. 191-199

MMSD (2002), Breaking New Ground: Mining, Minerals and Sustainable Development, Earthscan Publications Ltd, London and Sterling, VA

Moore, Mick (2000), Political Underdevelopment, The Institute of Development Studies, Sussex University, UK 
Pegg, Scott (2003), Poverty Reduction or Poverty Exacerbation? World bank Group Support for Extractive Industries In Africa, Department of Political Science, Indiana University Purdue University, Indianapolis

Porter, Michael E. (1998), On Competition, Harvard Business Review Books

Power, Thomas Michael (2002), Digging to Development? A Historical Look at Mining and Economic Development, Washington, D.C., Oxfam America

Ross, Michael L (2002), Comments on “Treasure or Trouble? Mining in Developing Countries”, UCLA Department of Political Science

Ross, Michael L (2001), Extractive Sectors and the Poor, Washington, D.C., Oxfam America

Ross, Michael L (1999), The Political Economy of the Resource Curse, World Politics No. 51 (January 1999), p.p. 297-322

2001), Sachs, Jeffrey D. and Warner, Andrew (1995), Natural Resource Abundance and Economic Growth, (Development Discussion Paper No. 517a, Harvard Institute for International Development, Harvard University, Cambridge, MA)

Scorecard for the Broad Based Socio-Economic Empowerment Charter for the South African Mining Industry, www.mineweb.com, 2003

Shafer, D Michael (1986), Undermined: The Implications of Mineral Export Dependence for State Formation in Africa, Third World Quarterly, 8(3), p.p. 916-953

Snider, Lewis W. (1996), Growth, Debt, and Politics: Economic Adjustment and the Political Performance of Developing Countries, Westview Press, Boulder, Colorado

Solomon, Michael H (2004), Critical Issues in Developing a Mining-related Poverty Reduction Strategy for the United Republic of Tanzania, UNDP, Dar es Salaam

Steele, Paul (2004), Pro-poor Growth or Boom and Bust? Coalitions for change to increase sustainability: The contribution of natural resources and the environment to pro-poor growth (A draft framework), Institute of Policy Studies, UK

Stijns,J.P.(2001), "Natural Resource Abundance and Economic Growth Revisited”, accessed on 21/8/2003 at URL; http://econwpa.wustl.edu/eps/dev/papers/0103/0103001.pdf3/wot

Stites, Elizabeth (2003), Extractive Industries and Poevrty Reduction Startegy Papers, Oxfam America, Washington D.C. 
Takizawa, Hajima; Gardner, Edward H.; and Ueda, Kenichi (2004), Are Developing Countries Better Off Spending Their Oil Wealth Upfront? IMF Working Paper No. 04/141, Washington, International Monetary Fund

Tilton, John E (1996), Exhaustible Resources and Sustainable Development: Two Different Paradigms, Resources Policy, Vol. 22, Nos 1-2, p.p. 91-97

Weber-Fahr, M.; Strongman, J.; Kunanayagam, R.; McMahon, G.; and Sheldon, C. (2001), Mining and Poverty Reduction, www.worldbank.org

World Bank, IFC (2002), Treasure or Trouble? Mining in Developing Countries, www.worldbank.org

Wright, Gavin (1990), The Origins of American Industrial Success, 1879-1940, American Economic Review No.80 (1990), p.p. 651-668 


\section{Endnotes}

${ }^{2}$ Learning-by-doing leads to lower production costs over time, and as a result, greater productivity and profitability, other factors the same. There is little to suggest, however, that mining is characterized by less internal learning than manufacturing. The sector has experienced a revolution in the areas of mechanization and automation over the last several decades. Moreover, there is little evidence that natural-resource dependent nations have lower rates of human capital accumulation than resource-poor nations, which we would expect if resource industries, including mining, had lower external learning-by-doing than other economic sectors.

${ }^{3}$ The effects of the Dutch Disease include (i) high inflation and currency appreciation; (ii) rise in input costs, especially wages; (iii) expansion or shrinking of the non-traded goods and services sector due to growth-inhibiting effects of rising input costs, or growth-promoting effects of higher incomes and demand respectively; and (iv) reallocation of resources (financial and human), from less attractive sectors such as agriculture and manufacturing to the booming minerals sector, with the resulting contraction and loss of competitiveness in those sectors.

${ }^{4}$ According to Mick Moore, political underdevelopment largely results from the ways in which states have been created and political authority shaped. Politically underdeveloped states are too independent of their own citizens due to (a) strong external financial and/or military support for state elites; (b) heavy dependence of states on "unearned income"; and (c) capacity of state elites and challengers to use control of commodity exports to purchase overwhelming armed force. Possession of natural resources promotes or locks in political underdevelopment, creating a vicious circle of negative outcomes.

${ }^{5}$ These include economic and social impacts, such as taxes and royalties, job creation, linkages to the local economy through procurement of goods and services, investments in physical infrastructure, human and social capital creation, technology and knowledge transfer, induced development, and other impacts.

${ }^{6}$ Porter (1998) defines a cluster as "geographic concentrations of interconnected companies and institutions in a particular field". Clusters encompass an array of companies of linked industries and other entities important to competition. They include, for example suppliers of specialized inputs such as components, machinery and services, and providers of specialized infrastructure. This concentration of expertise among closely linked industries and companies catalyses a growth trajectory because of extensive investment in specialized factors of production. Clusters often extend downstream to customers and to manufacturers of complementary products and to companies in industries related by skill, technology or common inputs. Many clusters include governmental and other institutions - such as universities, standards setting agencies, think tanks, vocational training providers and trade associations - that provide specialized training, education, information, design services, research and technical support.

${ }^{6}$ ILO (ILO, 1999) estimates that 3.0-3.7 million people are employed directly in small-scale mining in Africa; 6.7-7.2 million in Asia/Pacific countries; 1-4-1-6 million in Latin America; and about 0.4-0.5 
million in the rest of the world. Approximately 80-100 million people depend on the sub-sector for their livelihood.

${ }^{7}$ The Yaounde Vision was adopted during a joint ECA/UNDESA Seminar on "Artisanal and Small-scale Mining in Africa: Identifying Best Practices and Building Sustainable Livelihoods of Communities", held in Yaounde, Cameroon from 18 to 22 November, 2002

8 See www.casmsite.org 